\title{
Growth Response of Dwarf Lablab Bean (Lablab purpureus (L.) Sweet) to Sowing Date and Photoperiod
}

\author{
Sung Eun Kim, Hiroshi Okubo and Yasushi Kodama* \\ Laboratory of Horticultural Science, Faculty of Agriculture, Kyushu University 46-01, Fukuoka 812
}

\begin{abstract}
Summary
Effects of sowing dates and photoperiod on the growth habit in stem determinate type dwarf lablab bean (Lablab purpureus) were investigated. 1. The plants in the greenhouse showed an indeterminate growth habit when the seeds were sown during June and August, but determinate when sown in any other months of the year. 2. A photoperiod longer than $13 \mathrm{hr}$ caused an indeterminate growth habit. It is suggested that the determinate growth habit of a plant is controlled by photoperiod, temperature or a combination of both.
\end{abstract}

\section{Introduction}

Lablab bean or hyacinth bean (Lablab purpureus; synonym, Dolichos lablab L.) has been cultivated in India since earliest times (Purseglove, 1977). The immature pods and tender seeds are very popular there and elsewhere in the tropics. It is usually twining, but bushy forms are also reported to occur (Smartt, 1976; Purseglove, 1977). Both forms are grown in some limited areas of Japan, but the crop has no big market (Yasui, 1988). Flowers of the plant also have ornamental value and a few cultivars have been developed for that purpose (Yamashita, 1989).

The crop is photoperiodically responsive (Schaaffhausen, 1963; Purseglove, 1977); both long- and short-day cultivars exist. Day neutral accessions were also reported in Australia (Ison and Hopkinson, 1985). Both the garden and field cultivars in India, however, are sown during summer and harvested from fall to spring of the following year (Purseglove, 1977). In Bangladesh, the crop remains available in markets for a short period from November to March (Chowdhury et al., 1989). These reports indicate that these cultivars are all short-day plants, and that long-day cultivars are not commercially available.

Dwarf (determinate bush type) varieties have a

Received for publication 16 January 1992.

* Present address : Oita Prefecture Office, Oita 870. potential for more extensive cultivation of the crop, because 1) the plants require no support system, 2) the pods mature uniformly, and 3) the crop is amenable to mechanical harvesting, all of which can reduce cost and labor. The one disadvantage of the bush type is that their yields are less than those of the normal twining cultivars.

There are few reports on the growth responses of the crop to certain environmental factors besides photoperiod. The present investigation was undertaken to clarify the growth habit of a dwarf variety of lablab bean plant under different environmental conditions.

\section{Materials and Methods}

A dwarf variety of lablab bean introduced from India was used in the experiments. Seeds have been multiplied at Kyushu University for several years.

\section{Effects of sowing date on growth habit}

Seeds were sown in vermiculite on the 17 th of every month from January to December, 1990. Four to eight days were required for germination, and the difference was dependent on sowing date. After germination, the seedlings were transplanted in a mixture of pumice and vermiculite $(3: 1$ by volume) in plastic pots, $12 \mathrm{~cm}$ in diameter. They were grown in a greenhouse from January to midApril or a plastic-film greenhouse from mid-April with fan ventilation in the summer. The green- 
house was heated to maintain the minimum temperature of $15^{\circ} \mathrm{C}$ in winter, but the plastic-film greenhouse was unheated until the plants stop growing. The plants were fertilized with a $0.1 \%$ solution of a compound fertilizer, OK-F-1 (N: $\mathrm{P}_{2} \mathrm{O}_{5}: \mathrm{K}_{2} \mathrm{O}=15: 8: 17$, Otsuka Chemical Co.) when required. Twenty plants were used in each treatment.

\section{Effects of photoperiod on growth habit}

Seeds were sown on 7 September 1990 as described above and grown in the greenhouse maintained at a minimum of $15^{\circ} \mathrm{C}$. On 12 September, the seedlings were subjected to $11,12,13,14$, and $15 \mathrm{hr}$ daylengths until 20 December (105 days after sowing) in the greenhouse. Different daylengths were achieved by exposing plants to $8 \mathrm{hr}$ basic natural light (covering the plants from 5:00 p.m. to 9:00 a.m. of the following day) and extending daylengths with an incandescent lamp $\left(14.8 \mu \mathrm{mol} \cdot \mathrm{m}^{-2} \cdot \mathrm{sec}^{-1}\right)$. The coverings were ventilated during the daylight hours to prevent the temperature from rising. Forty plants were used in each treatment.

\section{Results}

The common form of a dwarf variety of the plant at the stage of immature pod growth and flowering is shown in Fig. 1. Flowers and immature pods are on the main stem and on the two 1st

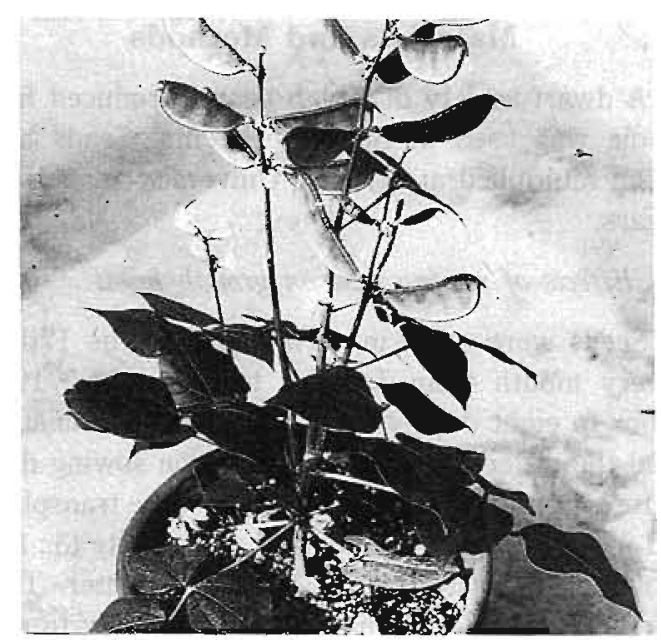

Fig. 1. A dwarf variety of lablab bean plant at its immature pod and flowering stage. order laterals. Flower buds just before anthesis are visible on the top of the other 1st order lateral in the photograph. It is a determinate and dwarf type plant; the apex of the main stem usually terminates after flower bud formation at 8 th to the 10 th node, and the laterals grow and terminate in the same sequence, whereas indeterminate twining varieties have more internodes. Internode lengths of the determinate plant are also shorter than are those of the twining varieties. The plant height ranges from 40 to $50 \mathrm{~cm}$, whereas that of twining varieties varies from 3 to $4 \mathrm{~m}$. The first flowers of the dwarf variety open on the main stem, and then the flowering occurs acropetally on each apex of the lateral shoots, whereas the basal flower buds of the twining variety open first, followed by the more distal ones, i.e., acropetally (Fig. 2).

\section{Effects of sowing date on growth habit}

The average maximum temperature in the greenhouses was higher than $30^{\circ} \mathrm{C}$ during 20 March and 20 August; it gradually decreased thereafter. The average minimum temperature during 20 June and 20 August was higher than $22^{\circ} \mathrm{C}$, and it was about $10^{\circ} \mathrm{C}$ from 10 October to the end of February. The latitude in Fukuoka is $33.35^{\circ} \mathrm{N}$. The maximum and minimum daylengths during the experiment were $14 \mathrm{hr} 24 \mathrm{~min}$ on 21 June 1990 and 9 hr 56 min on 21 December 1990.

All plants showed determinate growth habit when the seeds were sown during January and May (Table 1 and Fig. 3); the first inflorescence opened on the main stem between the 7th and 9th node followed by the flowering on the 1st order laterals. Indeterminate growth of the plants occurred over the period of June- to July-sowing when all the inflorescences appeared on the laterals and not on the main stem. The determinate growth habit was observed when the seeds were sown after August. The plant height and number of nodes increased in plants sown from January to June; those sown in June grew tallest and had the most nodes. Their number of nodes was more twice that of plants sown between January and May and between August and December.

Lengths of the 2nd and 3rd internodes were always very short (Fig. 3). There was no significant difference between lengths of the 1st to 7 th internodes of plants in the January to April sowing. When sown in May, the 7th and 8th internodes 


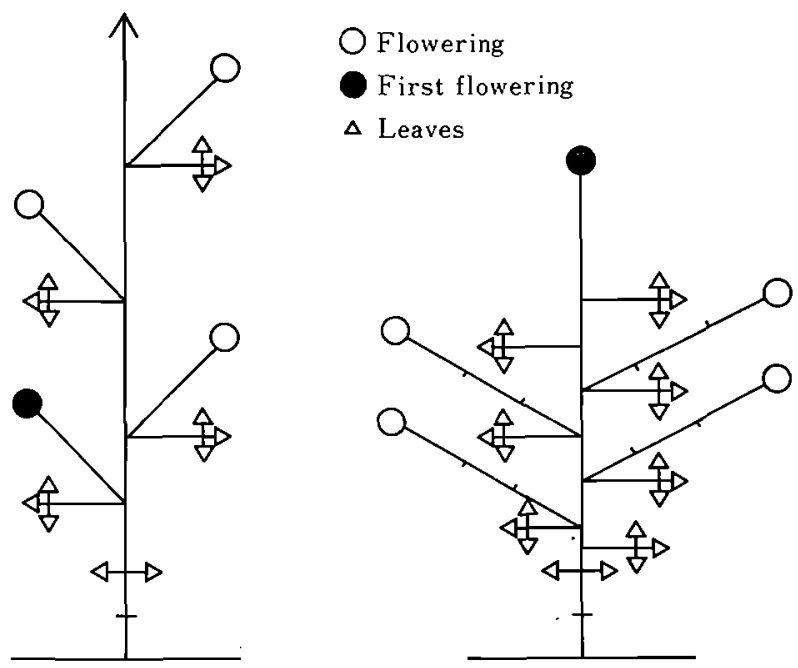

Fig. 2. Schematic drawing of flowering order in dwarf (right) and twining (left) varieties of lablab bean.

Table 1. Effect of sowing date on growth habit of dwarf lablab bean plant.

\begin{tabular}{lccc}
\hline \hline Sowing date & $\begin{array}{c}\text { Plant height } \\
(\mathrm{cm})\end{array}$ & $\begin{array}{c}\text { Number of nodes on } \\
\text { main stem }\end{array}$ & $\begin{array}{c}\text { Growth } \\
\text { habit }^{2}\end{array}$ \\
\hline 17 January & $24.5 \mathrm{~b}$ & $8.2 \mathrm{def}$ & $\mathrm{D}$ \\
17 February & $23.2 \mathrm{~b}$ & $7.4 \mathrm{~cd}$ & $\mathrm{D}$ \\
17 March & $30.0 \mathrm{~b}$ & $7.5 \mathrm{de}$ & $\mathrm{D}$ \\
17 April & $29.1 \mathrm{~b}$ & $8.3 \mathrm{ef}$ & $\mathrm{D}$ \\
17 May & $49.6 \mathrm{c}$ & $7.6 \mathrm{de}$ & $\mathrm{D}$ \\
17 June & $175.7 \mathrm{e}$ & $17.9 \mathrm{i}$ & In \\
17 July & $106.8 \mathrm{~d}$ & $14.0 \mathrm{~h}$ & In \\
17 August & $46.7 \mathrm{c}$ & $10.3 \mathrm{~g}$ & $\mathrm{D}$ \\
17 September & $52.7 \mathrm{C}$ & $9.0 \mathrm{f}$ & $\mathrm{D}$ \\
17 October & $26.7 \mathrm{~b}$ & $6.2 \mathrm{ab}$ & $\mathrm{D}$ \\
17 November & $11.8 \mathrm{a}$ & $6.6 \mathrm{bc}$ & $\mathrm{D}$ \\
17 December & $22.6 \mathrm{~b}$ & $5.5 \mathrm{a}$ & $\mathrm{D}$ \\
\hline
\end{tabular}

${ }^{z} \mathrm{D}$; determinate, In; indeterminate.

Mean separation within columns by Duncan's multiple range test, $5 \%$.

elongated, and the internode lengths of the 6 th and above were around $10 \mathrm{~cm}$ each in June-sown plants. There was, however, no specific internode that was longer than others. A small decrease was observed in the lengths of the 5 th to 8 th internodes of the July-sown plants, but the lengths of the 6 th and above internodes were also around $10 \mathrm{~cm}$. When sown after September, the length of each internode decreased to the level of that of the plants sown in or before May.

\section{Effects of photoperiod on growth habit}

The average maximum and minimum temperatures during the experiment were 28.9 and $17.0^{\circ} \mathrm{C}$, respectively, with a small difference among the daylength treatments.

Longer daylengths significantly increased the days to first flowering, plant height, and number of nodes; they changed the growth habit from determinate to indeterminate (Table 2 and Fig. 4). Percentages of flowering were still high in longer 


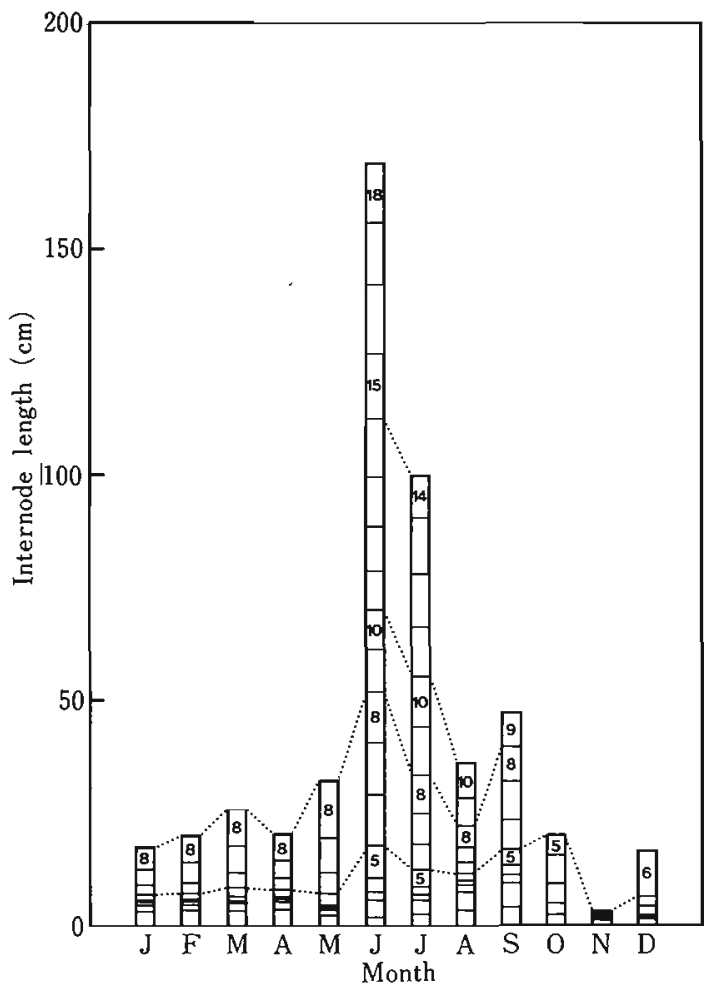

Fig. 3. Effect of sowing date on internode length. Numerals in columns are node numbers.

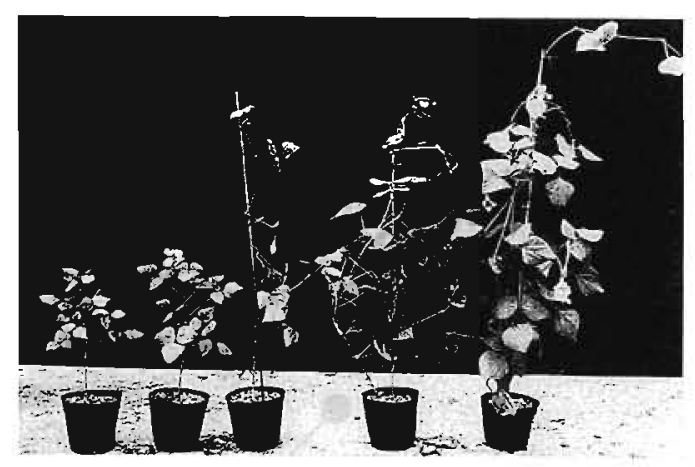

Fig. 4. Plant shape 105 days after cultivation under different daylength. Left to right; $11,12,13,14$ and $15 \mathrm{hr}$.

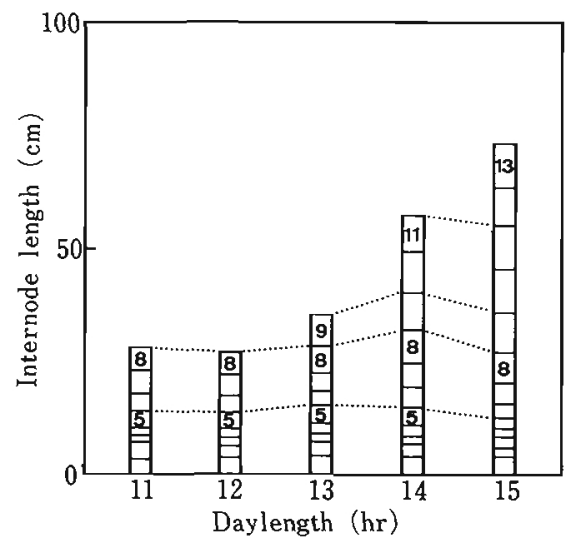

Fig. 5. Effects of daylength on internode length. Numerals in columns are node numbers.

Table 2. Effects of daylength treatment on growth habit of dwarf lablab bean plant.

\begin{tabular}{cccccc}
\hline \hline $\begin{array}{c}\text { Daylength } \\
(\mathrm{hr})\end{array}$ & $\begin{array}{c}\text { Plant height } \\
(\mathrm{cm})\end{array}$ & $\begin{array}{c}\text { Number of nodes } \\
\text { on main stem }\end{array}$ & $\begin{array}{c}\text { Growth } \\
\text { habit }^{z}\end{array}$ & $\begin{array}{c}\text { Days to first } \\
\text { flowering }\end{array}$ & $\begin{array}{c}\text { \% of } \\
\text { flowering }^{\mathrm{y}}\end{array}$ \\
\hline 11 & $33.1 \mathrm{a}$ & $8.0 \mathrm{a}$ & $\mathrm{D}$ & $57.6 \mathrm{a}$ & 97.5 \\
12 & $35.3 \mathrm{ab}$ & $8.1 \mathrm{ab}$ & $\mathrm{D}$ & $63.3 \mathrm{a}$ & 81.1 \\
13 & $44.3 \mathrm{~b}$ & $9.2 \mathrm{~b}$ & $\mathrm{D} / \mathrm{I}$ & $75.4 \mathrm{~b}$ & 90.0 \\
14 & $63.0 \mathrm{c}$ & $11.0 \mathrm{c}$ & In & $81.4 \mathrm{c}$ & 80.0 \\
15 & $76.8 \mathrm{~d}$ & $12.5 \mathrm{~d}$ & In & $82.6 \mathrm{c}$ & 80.0 \\
\hline
\end{tabular}

${ }^{2} \mathrm{D}$; determinate, In; indeterminate.

${ }^{y}$ Days to first flowering from seed sowing. Irrespective where the first flower opened.

${ }^{x}$ Irrespective where the first flower opened.

Mean separation within columns by Duncan's multiple range test, $5 \%$.

photoperiods, whether the flowers were on the main stem or laterals.

Differences among internode lengths up to the 8th internode were not significant under any photoperiod (Fig. 5). Extending the daylengths to 14 and $15 \mathrm{hr}$ increased the number of nodes to 11 
and 13 , respectively. The length of internodes above the 8th node was about $10 \mathrm{~cm}$, which is longer than those below it. There was, however, no specific internode that outgrew others at $15 \mathrm{hr}$.

\section{Discussion}

It is clear that the stem determinate growth habit of the plant is controlled by the environment, probably photoperiod, temperature or a combination of both. Dwarfness or stem determinate growth habit of plants is commonly recognized to be genetically controlled and independent of external factors. For example in leguminous crops, inheritance of determinate growth habit has been well studied. Yarnell (1965) reported that a single gene difference separates the determinate from the indeterminate growth habit in Phaseolus vulgaris. Bernard (1972) confirmed that the inheritance of the determinate stem type vs indeterminate stem in soybean was monogenic.

A few reports on environment-dependent stem determinate growth habit in plants are available. Temperature effect on controlling stem determinate growth habit in soybean was reported (Inouye et al., 1979); some plants shifted from determinate growth habit at a constant temperature of $20^{\circ} \mathrm{C}$ to indeterminate at 30 and $35^{\circ} \mathrm{C}$ when grown from early May to mid-July during which the daylength was between $13 \mathrm{hr} 30 \mathrm{~min}$ and 14 hr $20 \mathrm{~min}$. Determinate cowpea (Vigna unguiculata) elongated and became indeterminate in $27^{\circ} / 24^{\circ} \mathrm{C}$ (day/night) and $33^{\circ} / 24^{\circ} \mathrm{C}$ as compared with $27^{\circ} / 19^{\circ} \mathrm{C}$ and $33^{\circ} / 19^{\circ} \mathrm{C}$ under $12 \mathrm{hr}$ photoperiod (Summerfield and Wien, 1980). These reports both indicate the role of temperature on the growth habit. There were, however, no more detailed physiological studies on the phenomenon in these plants.

That the plants flowered when the plants were exposed to photoperiods of 11 to $15 \mathrm{hr}$, and that the number of days from seeding to flowering were affected depending on the daylength may indicate that the plant used in this study may well be a facultative short-day plant. Low temperature effect on flowering of the plant should be considered, because the second experiment was conducted in the fall to winter season. Flowering induction of short day plants by low temperature under long days has been recognized not only in leguminous crops, lablab bean cv. Rongai (Hill,
1967) and winged bean (Herath and Ormrod, 1979; Uemoto et al., 1982), but also in tobacco (Roberts and Struckmeyer, 1938) and begonia (Heide, 1969).

Results of the second experiment reveal that the increase in plant height after exposure to more than $13 \mathrm{hr}$ daylengths is attributable to the increase in the number of internodes and not to the increase of internode lengths, especially those of the lower internodes. The temperature was nearly the same in any daylength treatment so that the number of internodes may be a function of photoperiod rather than those of temperature. Although the mean number of internodes increased at $15 \mathrm{hr}$ day, it was considerably less than that of plants growing under natural longest daylength of June-sowing. Thus, temperature also seems to have a role on the number of internodes. Our data suggest that daylength and/or temperature control stem determinate growth habit of the plant, a phenomenon which should be examined to clarify whether photoperiod and/or temperature controls the length and number of internodes.

Control of morphogenesis by light quality should also be considered. Kretchmer et al. (1977) showed the morphological shift in Phaseolus vulgaris from indeterminate bush to indeterminate climbing type by red-light interruption. However, this is not a permanent genetic conversion of the growth habit from determinate to indeterminate or vice versa.

To cultivate the determinate type of lablab bean in Japan under structure, we found that when the seeds are sown in mid-May, the plants will assume a determinate growth habit, require the shortest number of days to flower, and give fairly good yields. If seeds are sown in late fall to early spring, the growth will be slow; when sown in summer to early fall, the growth will be twining.

\section{Literature Cited}

Bernard, R.L. 1972. Two genes affecting stem termination in soybeans. Crop Sci. $12: 235-239$.

Chowdhury, A.R., M. Ali and H.A. Quadir. 1989. Aspects of pollination and floral biology of lablab bean (Lablab purpureus L. Sweet).. J. Japan. Soc. Hort. Sci. 58 : 665-671.

Heide, O.M. 1969. Environmental control of sex expression in Begonia. Z. Pflanzenphysiol. $61: 279-285$.

Herath, H.M.W. and D.P. Ormrod. 1979. Effects of temperature and photoperiod on winged beans [Psophocarpus tetragonolobus (L.) D.C.]. Ann. Bot. 
43: 729-736.

Hill, G. D. 1967. A requirement for chilling to induce flowering in Dolichos lablab cv. Rongai. Papua New Guinea Agric. J. 19:16-17.

Inouye, J., S. Shanmugasundaram and T. Masuyama. 1979. Effects of temperature and daylength on the flowering of some photoinsensitive soybean varieties. Japan. J. Trop. Agr. $22: 167-171$.

Ison, R. L. and J.M. Hopkinson. 1985. Pasture legumes and grasses of warm climate regions. p. 203-251. In : A.H. Halevy (ed.). Handbook of flowering. Vol. I. CRC Press, Boca Raton, Florida.

Kretchmer, P. J., J.L. Ozbun, S. L. Kaplan, D.R. Laing and D.H. Wallace, 1977. Red and far-red light effects on climbing in Phaseolus vulgaris L. Crop Sci. $17: 797-799$.

Purseglove, J.W. 1977. Tropical crops Dicotyledons. p. 273-276. Longman, London.

Roberts, R.H. and B.E. Struckmeyer. 1938. The effects of temperature and other environmental factors upon the photoperiodic responses of some of the higher plants. J. Agric. Res. $59: 633-678$.

Schaaffhausen, R.V. $1963 . \quad$ Dolichos lablab or hyacinth bean: Its use for feed, food and soil improvement. Econ. Bot. $17: 146-153$.

Smartt, J. 1976. Tropical pulses. p. 61-62. Longman, London.

Summerfield, R.J. and H.C. Wien. 1980. Effects of photoperiod and air temperature on growth and yield of economic legumes. p. 17-36. In : R. J. Summerfield and A.H. Bunting (eds.). Advances in iegume science. Her Majesty's Stationery Office, London.

Uemoto, S., K. Fujieda, M. Nonaka and Y. Nakamoto. 1982. Effects of photoperiod and temperature on the raceme budding of winged beans (Psophocarpus tetragonolobus). Bull. Inst. Trop. Agr. Kyushu Univ. $5: 59-70$.

Yamashita, F. 1989. Fujimame. p. 221. In: Y. Tsukamoto et al. (eds.). The grand dictionary of horticulture. Vol. 4. Shogakukan, Tokyo.

Yarnell, S.H. 1965. Cytogenetics of the vegetable crops. IV. Legumes (continued). Bot. Rev. $31: 247-330$.

Yasui, H. 1988. Fujimame. p.1016-1019. In : S. Nishi et al. (eds.). Yasaiengei daijiten. Yokendo, Tokyo.

矮性フジマメ（Lablab purpureus（L.）Sweet）の播種日および日長に対する生育反応

\author{
金 成恩 - 大久保 敬 - 児玉 泰* \\ 九州大学農学部 812 福周市東区箱崎
}

\begin{abstract}
摘 要
丵性型矮性フジマメの芯止まり形質に及ばす播種日 および日長の影響を調べた。 1 年のうち 6 月および 7 月に播種したフジマメはビニルハウス内で䓯性を示し たが他の時期に播種した場合は芯止まり型を示した。 ガラス温室内で11時間から15時間までの日長条件下で

生育させたフジマメは12時間日長以下では丵性型を示 したが，13時間日長以上では䓪性を示した，節数なら びに節間長の調査から矮性フジマメの芯止まり形質は 温度，日長あるいはその双方によって制御されている ことが示唆された。
\end{abstract}

*現在：大分県庁. 